\title{
PENERAPAN METODE PROBLEM POSING DALAM MENINGKATKAN HASIL BELAJAR SISWA MATA PELAJARAN BAHASA INDONESIA KELAS IV SD NEGERI 163099 TEBING TINGGI
}

\author{
Bainim Simarmata \\ Surel : bainimsimarmata0304@gmail.com
}

\begin{abstract}
This study aims to improve student learning outcomes of Indonesian subjects through problem posing method. This classroom action research is conducted in 2 cycles with four stages: planning, implementation, observation, reflection. The subjects of this research are fourth grade students of SD Negeri 163099 Tebing Tinggi as many as 34 students. This research uses qualitative decriptive analysis technique. The result of the research shows that the use of problem posing method of Indonesian subjects can improve students 'learning achievement which is marked by students' learning completeness improvement, that is pre cycle $(73,52 \%)$, cycle I (82,35\%), cycle II (94,11\%) And declared successful classically $94.11 \%$.
\end{abstract}

Keywords: Problem Posing, Bahasa Indonesia, Learning Outcomes

\begin{abstract}
ABSTRAK
Penelitian ini bertujuan untuk meningkatkan hasil belajar siswa mata pelajaran Bahasa Indonesia melalui metode problem posing. Penelitian tindakan kelas ini dilaksanakan sebanyak 2 siklus dengan empat tahapan yaitu: perencanaan, pelaksanaan, observasi, refleksi. Subjek penelitian ini adalah siswa kelas IV SD Negeri 163099 Tebing Tinggi sebanyak 34 siswa. Penelitian ini menggunakan teknik analisis dekriptif kualitatif. Hasil penelitian menunjukkan bahwa penggunaan metode problem posing mata pelajaran Bahasa Indonesia dapat meningkatkan hasil belajar siswa yang ditandai dengan peningkatan ketuntasan belajar siswa, yaitu pra siklus $(73,52 \%)$, siklus I $(82,35 \%)$, siklus II $(94,11 \%)$ dan dinyatakan berhasil secara klasikal 94,11\%.
\end{abstract}

Kata Kunci : Problem Posing, Bahasa Indonesia, Hasil Belajar

\section{PENDAHULUAN}

Pembelajaran

Indonesia diarahkan untuk

meningkatkan kemampuan peserta

didik untuk berkomunikasi dalam

bahasa Indonesia dengan baik dan benar, baik secara lisan maupun tulis, serta menumbuhkan apresiasi terhadap hasil karya kesastraan manusia Indonesia. Ruang lingkup mata pelajaran Bahasa Indonesia mencakup komponen kemampuan berbahasa dan kemampuan bersastra yang meliputi aspek-aspek sebagai berikut: mendengarkan, berbicara, membaca, dan menulis.

Pembelajaran bahasa Indonesia di SD mempunyai peranan

Guru SD Negeri 163099 Tebing Tinggi 
yang sangat penting dalam membentuk kebiasaan, sikap, serta kemampuan dasar yang diperlukan siswa untuk perkembangan selanjutnya. Selain itu pengajaran tersebut harus dapat membantu siswa dalam pengembangan kemampuan berbahasa yang diperlukannya, bukan saja untuk berkomunikasi, melainkan juga untuk menyerap berbagai nilai serta pengetahuan yang dipelajari.

Menurut Yusi Rosdiana dkk. (2007:121), fungsi bahasa Indonesia sesuai dengan kedudukannya sebagai bahasa Negara (UUD 1945 Bab XV Pasal 36), yaitu (a) bahasa resmi kenegaraan, (b) Bahasa pengantar dalam dunia pendidikan, (c) alat perhubungan pada tingkat nasional untuk kepentingan perencanaan dan pelaksanaan pembangunan serta kepentingan pemerintahan, (d) alat pengembangan kebudayaan, ilmu pengetahuan dan teknologi.

Selama ini pada umumnya model pembelajaran yang dikembangkan di sekolah cenderung dilakukan secara individu, pengelolaan pembelajaran menjadi tanggung jawab guru yang bersangkutan secara individual, baik dalam merencanakan, melaksanakan, maupun menilai pembelajaran siswa, ketika dihadapkan dengan tuntutan kurikulum yang sangat kompleks dan kondisi nyata yang kurang kondusif, guru seringkali menjadi tidak berdaya dan memiliki keterbatasan untuk dapat mengimplementasikan kurikulum sesuai dengan apa yang diharapkan.

Salah satu tugas pendidik atau guru adalah menciptakan suasana pembelajaran yang dapat memotivasi siswa untuk senantiasa belajar dengan baik dan bersemangat. Suasana pembelajaran yang demikian akan berdampak positif dalam pencapaian prestasi belajar yang optimal. Oleh karena itu guru sebaiknya memiliki kemampuan dalam memilih metode dan media pembelajaran yang tepat.

Pembelajaran yang efektif menurut menuntut kemampuan guru untuk : 1) merancang bahan ajar yang mampu menarik dan memotivasi siswa untuk belajar, 2) menggunakan berbagai strategi pembelajaran, 3) mengelola kelas agar tertib dan teratur, 4) memberitahu siswa tentang perilaku yang diharapkan untuk dimiliki siswa, 5) menjadi narasumber, fasilitator, dan motivator yang handal, 6) memperhitungkan karakteristik intelektual, sosial, dan cultural siswa, 7) terampil memberikan pertanyaan dan balikan, 8) interview bersama siswa (Ani, dkk. 2007:16)

$\begin{array}{llr}\text { Masalah } & \text { yang } & \text { sering } \\ \text { dilontarkan dalam } & \text { pelajaran }\end{array}$
mengarang adalah kurang mampunya siswa menggunakan bahasa Indonesia yang baik dan benar. Hal tersebut dapat dilihat pada pilihan kata yang kurang tepat, kalimat yang kurang efektif, sukar mengungkapkan gagasan karena kesulitan memilih kata atau membuat kalimat, bahkan 
kurang mampu mengembangkan ide secara teratur dan sistematik, disamping kesalahan masalah ejaan

Hasil belajar siswa kelas IV SD Negeri 163099 pada kondisi awal masih dikategorikan kurang baik. Hal ini dapat dilihat dari nilai evaluasi ulangan harian pra siklus yang rendah yaitu dengan rata-rata nilai 63,5 dengan jumlah siswa yang lulus KKM 25 siswa $(73,52 \%)$. Nilai KKM yang ditetapkan adalah 70 .

Untuk dapat mengatasi masalah tersebut diatas, maka peneliti menerapkan metode problem posing pada pembelajaran bahasa Indonesia. Problem posing merupakan kegiatan yang mengarah pada sikap kritis dan kreatif. Sebab, dalam model pembelajaran ini mengharuskan siswa membuat pertanyaan dari informasi yang diberikan. Padahal, bertanya merupakan pangkal semua kreasi. Orang yang memiliki kemampuan berkreasi dikatakan memiliki sikap kreatif.

Problem Posing memberikan kelebihan pada siswa dalam hal memperoleh pengetahuan dengan cara menganalisa suatu masalah. Hal ini dapat dilihat dari tiga hal yaitu pengulangan masalah, visualisasi masalah dan penalaran kualitatif siswa (Cankoy dan Darbaz, 2010). Sejalan dengan pernyataan diatas, Yaya S. Kusumah (2004: 8) problem posing adalah pengajuan masalah sebagaimana yang dinyatakan sebagai pendekatan, pengajuan masalah berkaitan dengan alat yang perlu dimiliki guru sehingga mampu mendorong dan melatih siswa dalam merumuskan pertanyaan dan kemudian menentukan penyelesaiannya. Pendekatan ini lebih ditekankan pada kegiatan membentuk soal yang dilakukan oleh siswa sendiri. Hal ini memberi kesempatan yang luas kepada siswa untuk mengkonstruk pengetahuan sesuai dengan perkembangan pengetahuan berfikirnya.

Pembelajaran problem posing adalah pengajaran yang dilakukan melalui cara pengajuan soal oleh siswa dan cara penyajiannya juga oleh siswa sendiri. Dalam hal ini, problem posing merupakan salah satu pengajaran yang menuntut adanya keaktifan siswa baik mental maupun fisik.

Langkah-langkah dalam pelaksanaan metode pembelajaran problem posing dalam pembelajaran operasi hitung pecahan yang dikemukakan oleh Syarifulfahmi (2009) sebagai berikut:

1. Membuka kegiatan pembelajaran.

2. Menyampaikan tujuan pembelajaran.

3. Menjelaskan materi pelajaran (perkalian dan pembagian pecahan)

4. Memberikan contoh soal (perkalian dan pembagian pecahan)

5. Memberikan kesempatan kepada siswa untuk bertanya tentang halhal yang belum jelas. 
6. Memberikan kesempatan kepada siswa untuk membentuk soal dan menyele-saikannya (problem posing).

7. Mengarahkan siswa untuk membuat kesimpulan.

8. Membuat rangkuman berdasarkan kesimpulan yang dibuat siswa.

9. Menutup kegiatan pembelajaran.

Berdasarkan permasalahan tersebut maka alternatif pendekatan pembelajaran yang tepat pada mata pelajaran bahasa Indonesia yaitu dengan metode problem posing. Dalam problem posing, siswa diberi kegiatan untuk membuat/membentuk soal kemudian menyelesaikan/ memecahkan soal tersebut sesuai dengan konsep atau materi yang telah dipelajari.

Berdasarkan uraian pada latar belakang masalah, maka dapat dirumuskan permasalahan sebagai berikut: "Apakah dengan menggunakan pembelajaran metode problem posing meningkatkan hasil belajar bahasa Indonesia siswa kelas IV SD Negeri 163099 kota Tebing Tinggi Tahun pelajaran 2016/2017?"

Tujuan dari penelitian ini adalah untuk meningkatkan hasil belajar Bahasa Indonesia siswa kelas IV SD Negeri 163099 Tebing Tinggi tahun pembelajaran 2016/2017 melalui metode problem posing.

\section{METODE PENELITIAN}

Penelitian ini dilaksanakan pada bulan September sampai dengan bulan November 2016 pada semester ganjil tahun ajaran 2016/2017. Penelitian ini dilaksanakan dalam 2 siklus, yaitu siklus pertama selama 2 kali pertemuan dan siklus kedua selama 2 kali pertemuan. Peneliti mengambil lokasi penelitian tindakan kelas di SD Negeri 163099 Tebing Tinggi.

Subyek penelitian adalah siswa kelas IV SD Negeri 163099 Tebing Tinggi dengan jumlah siswa sebanyak 34 orang dengan 18 orang laki-laki dan 16 orang perempuan. Sumber data yang digunakan adalah siswa dan teman sejawat. Pada Penelitian tindakan kelas data yang dikumpulkan dapat berbentuk kuantitatif maupun kualitatif. Data kuantitatif yang berupa nilai dianalisis dengan menggunakan analisis deskriptif komparatif yaiu membandingkan nilai tes kondisi awal, nilai tes setelah siklus I dan II yaitu nilai dari hasil ulangan harian siswa kelas IV SD Negeri 163099 pada siklus I dan II.

Metode penelitian yang digunakan dalam penelitian ini adalah Classroom Action Research atau penelitian tindakan kelas. Model penelitian tindakan kelas yang digunakan peneliti adalah sistem spiral refleksi diri yang dikembangkan oleh Kemmis dan Taggart yang dimulai dengan perencanaan, tindakan, pengamatan, dan refleksi. Masing-masing siklus terdiri dari dua kali pertemuan yaitu sebagai berikut: 


\section{Perencanaan}

Pada tahapan ini dilakukan berbagai persiapan dan perencanaan tindakan yang meliputi menyusun skenario pembelajaran berupa Rencana Pelaksaan Pembelajaran, mempersiapkan media pembelajaran dan alat observasi, dan membuat instrumen untuk evaluasi yang berupa soal tes tertulis. Selain mempersiapkan hal-hal tersebut, untuk dapat melaksanakan penelitian ini dengan tujuan yang jelas peneliti juga perlu menetapkan indikator ketercapaian dalam penerapan metode problem posing.

\section{Pelaksanaan}

\section{a. Siklus I}

Guru melakukan pembelajaran di dalam kelas dengan menggunakan panduan perencanaan yang telah dibuat. Siklus I dilakukan pada tanggal 2 Oktober 2016. Penerapan metode Penggunaan model problem posing diharapkan dapat memancing siswa untuk menemukan pengetahuan yang bukan dilibatkan dari ketidaksengajaan melainkan melalui upaya mereka untuk mencari hubungan-hubungan tersebut. Pada akhirnya, penemuan pertanyaan serta jawaban yang dihasilkan terhadapnya dapat menyebabkan perubahan dan ketergantungan pada penguatan luar pada rasa puas akibat keberhasilan menemukan sendiri, baik berupa pertanyaan atau masalah maupun jawaban atas permasalah yang diajukan.
Kompetensi dasar pada siklus ini yaitu membuat gambar/denah berdasarkan penjelasan yang didengar. Pada saat kegiatan pembelajaran berlangsung guru sebagai peneliti dibantu oleh para observer lainnya untuk melakukan pengamatan, mendokumentasi kegiatan, selain itu peneliti bertindak sebagai fasilitator, motivator dan sekaligus sebagai pengamat.

\section{b. Siklus II}

Guru melakukan pembelajaran di dalam kelas dengan menggunakan panduan perencanaan yang telah dibuat. Siklus II dilakukan pada tanggal 9 Oktober 2016. Siswa mengajukan pertanyaan sendiri mengenai materi yang dipelajari. Pada akhirnya, penemuan pertanyaan serta jawaban yang dihasilkan terhadapnya dapat menyebabkan perubahan dan ketergantungan pada penguatan luar pada rasa puas akibat keberhasilan menemukan sendiri, baik berupa pertanyaan atau masalah maupun jawaban atas permasalah yang diajukan.

Kompetensi dasar pada siklus ini adalah melengkapi percakapan yang belum selesai dengan memperhatikan penggunaan ejaan (tanda titik dua dan tanda petik). Pada saat kegiatan pembelajaran berlangsung guru sebagai peneliti dibantu oleh para observer lainnya untuk melakukan pengamatan, mendokumentasi kegiatan, selain itu 
peneliti bertindak sebagai fasilitator, motivator dan sekaligus sebagai pengamat.

\section{Observasi/Pengamatan}

Observasi digunakan untuk pengumpulan data aktivitas belajar bahasa Indonesia siswa dalam pembelajaran. Pengumpulan data melalui observasi dilakukan secara partisipatif, yang berarti pengamat ikut serta dalam kegiatan belajar mengajar yang dilakukan oleh subjek yang diamati (Sanjaya, 2010: 92). Pengamatan dilakukan peneliti sendiri dan dibantu oleh pengamat dan mencatat proses penerapan teknik pengajaran kolaborasi.

d. Refleksi

Peneliti mengkaji, melihat dan mempertimbangkan hasil atau dampak dari tindakan yang dilakukan berdasarkan lembar pengamatan yang diisi oleh pengamat. Kegiatan pada tahap refleksi meliputi kegiatan menganalisis, memahami dan membuat kesimpulan berdasarkan hasil observasi setiap siklus. menemukan kelebihan dan kelemahan tindakan perbaikan pembelajaran. Hasil analisis data yang dilaksanakan pada tahap ini akan dipergunakan untuk menemukan kelebihan dan kelemahan diri dalam merancang dan melakukan tindakan sebagai acuan.

Instrumen yang digunakan dalam penelitian ini adalah pedoman observasi, test hasil belajar, dan wawancara. Data aktivitas belajar dan kendala yang dihadapi selama proses pembelajaran dikumpulkan melalui observasi (lembar observasi terlampir). Hal-hal yang akan diobservasi adalah kegiatan lisan, kegiatan metrik, kegiatan emosional. Data hasil observasi, dan data hasil wawancara yang jenis datanya berupa pernyataan-pernyataan, dianalisis dengan menggunakan teknik analisis statistik deskriptif.

Metode pengumpulan data penelitian ini adalah tertulis dan observasi. Penelitian ini dikatakan berhasil apabila siswa telah memperoleh nilai ketuntasan secara klasikal minimal $85 \%$ dari jumlah siswa dengan rumus sebagai berikut :

Persentase Ketuntasan klasikal $=$ $\underline{\text { Jumlah siswa yang tuntas }} \times 100$ $\%$

Jumlah siswa yang mengikuti tes

\section{HASIL DAN PEMBAHASAN}

Berdasarkan observasi awal pada pra siklus, diketahui hasil belajar siswa pada prasiklus dalam memahami materi pelajaran agak sulit. Sebelum dilakukan metode problem posing pada saat pembelajaran, siswa yang aktif cenderung sedikit sedangkan lebih banyak didominasi oleh siswa yang kurang aktif dalam proses kegiatan belajar mengajar.

Pada tes awal kondisi pra siklus, diperoleh nilai rata-rata kelas 65, masih jauh dari yang telah ditetapkan yaitu $\geq 70$. Sedangkan 
besarnya persentase siswa yang belajar tuntas secara klasikal hanya sebesar 73,52\%. Nilai terendah pada tes awal ada-lah sebesar 55, sedangkan nilai tertinggi yang diperoleh siswa adalah 80. Berdasarkan hasil analisis tes awal tersebut, maka akan dila-kukan tindakan yang berupa penelitian tindakan kelas dalam rangka meningkatkan hasil belajar siswa dengan menggunakan metode pembelajaran problem posing.

Hasil penelitian tindakan kelas menunjukkan bahwa pengamatan yang dilakukan oleh mitra kolaborasi dan peneliti pada aktivitas guru dan siswa melalui penerapan metode problem posing pada mata pelajaran Bahasa Indonesia kelas IV SD Negeri 163099 Tebing Tinggi dapat dilihat pada Tabel 1 yaitu sebagai berikut :

Tabel 1. Peningkatan Hasil Belajar Siswa Pra Siklus, Siklus I dan II

\begin{tabular}{|c|c|c|c|}
\hline \multicolumn{2}{|c|}{ Peningkatan Hasil Belajar } & \multirow{2}{*}{ Keterangan } \\
\cline { 1 - 2 } $\begin{array}{c}\text { Pra } \\
\text { Siklus }\end{array}$ & $\begin{array}{c}\text { Siklus } \\
\text { I }\end{array}$ & $\begin{array}{c}\text { Siklus } \\
\text { II }\end{array}$ & \\
\hline 25 & 28 & 32 & $\begin{array}{c}\text { Jumlah } \\
\text { Siswa Lulus }\end{array}$ \\
\hline 73,52 & 82,35 & 94,11 & $\begin{array}{c}\text { Persentase } \\
\text { Ketuntasan } \\
\text { Belajar (\%) }\end{array}$ \\
\hline $\begin{array}{c}\text { Tidak } \\
\text { Tuntas }\end{array}$ & $\begin{array}{c}\text { Tidak } \\
\text { Tuntas }\end{array}$ & Tuntas & $\begin{array}{c}\text { Ketuntasan } \\
\text { Secara } \\
\text { Klasikal }\end{array}$ \\
\hline
\end{tabular}

Berdasarkan pengamatan peneliti dari tindakan prasiklus, siklus I dan II terjadi peningkatan hasil belajar pada jumlah siswa dan persen ketuntasan belajar secara klasikal. Pembelajaran siklus I menggunakan metode problem posing menunjukkan adanya pe-ningkatan hasil belajar siswa. Hasil analisis data nilai keterampilan siswa mengenai materi pelaran pada tes siklus I menunjukkan bahwa persentase hasil tes siswa yang belajar tuntas naik sebesar 8,83\% dibandingkan sebelum tindakan. Siswa yang belajar tuntas secara klasikal pada siklus I sebanyak 28 siswa atau sebesar $82,35 \%$.

Peningkatan tersebut belum memenuhi target atau indikator keberhasilan yang telah ditetapkan. Selain itu juga masih terdapat beberapa kekurangan dalam pelaksaan pembelajaran.

Hasil ulangan siswa pada pelajaran bahasa Indonesia di kelas IV masih tergolong kurang, yaitu memperoleh rata-rata 65 , sedangkan Kriteria Kelulusan Minimal (KKM) yang harus dicapai siswa adalah 70 . Dari 34 orang siswa yang mengikuti ujian pada pelajaran bahasa Indonesia hanya 28 orang siswa atau 82,35\% yang berhasil mendapatkan nilai di atas nilai 70. Hasil tersebut menunjukkan bahwa pada siklus pertama secara klasikal siswa belum tuntas belajar, karena siswa yang memperoleh nilai $\geq 70$ hanya sebesar $77,14 \%$ lebih kecil dari persentase ketuntasan yang dikehendaki yaitu sebesar $85 \%$. Sebanyak 28 orang siswa setelah dilakukan tes akhir siklus I hasil belajarnya meningkat. 
Hanya saja peningkatan yang terjadi belum optimal karena hasil belajar masih berada dalam kategori kurang dan indeks peningkatan hasil belajar masih berada dalam kategori rendah.

Meskipun demikian, terjadi peingkatan hasil belajar siswa dari pra siklus ke siklus I walaupun hasilnya belum sesuai dengan indikator keberhasilan. Hal ini membuktikan bahwa dengan penerapan metode problem posing dapat meningkatkan hasil belajar siswa kelas IV SD 163099 Tebing Tinggi. Pada saat kegiatan belajar siswa banyak yang suka bermain sendiri dan susah untuk diatur. Selain itu, menurut mitra kolaborasi guru dalam menyampaikan perintah atau penjelasan masih terkadang mengunakan bahasa yang susah dimengerti dan dipahami oleh siswa sehingga membuat siswa kebingungan.

Penggunaan metode Problem posing adalah salah satu cara yang efektif untuk mengembangkan keterampilan siswa untuk meningkatkan kemampuan dalam menerapkan konsep. Hal ini sesuai dengan pendapat Cankoy dan Darbaz, (2010) Problem Posing memberikan kelebihan pada siswa dalam hal memperoleh pengetahuan dengan cara menganalisa suatu masalah. Hal ini dapat dilihat dari tiga hal yaitu pengulangan masalah, visualisasi masalah dan penalaran kualitatif siswa.

Pada Tabel 1, metode pembelajaran problem posing pada siklus II diperoleh nilai rata-rata ulangan harian siswa adalah 73,23 dan ketuntasan belajar mencapai 94,11\% atau ada 32 siswa dari 34 siswa sudah tuntas belajar. Hasil tersebut menunjukkan bahwa pada siklus kedua secara klasikal sudah tuntas belajar, karena siswa yang memperoleh nilai $\geq 70$ sebesar 94,11 $\%$ sudah memenuhi kriteria dari persentase ketuntasan yang dikehendaki yaitu sebesar $85 \%$.

Dengan mencermati data hasil tes akhir siklus II, dapat dinyatakan bahwa terjadi peningkatan yang signifikan pada hasil belajar. Hal tersebut didukung berdasarkan jumlah siswa yang mengalami peningkatan hasil belajar. Sebanyak 32 orang siswa tuntas secara klasikal dari 34 siswa setelah dilakukan tes akhir siklus II hasil belajarnya meningkat. Siswa sudah semakin berani mengacungkan tangan terhadap hal yang belum dimengerti dan bersemangat mengkomunikasikan hasil kerja Hal ini menunjukkan bahwa pelaksanaan pembelajaran pada siklus II sudah lebih baik dari siklus I.

Dengan penerapan metode problem posing dapat meningkatkan penguasaan materi siswa untuk mata pelajaran Bahasa Indonesia. Hal ini terlihat dari perbandingan hasil belajar siswa sebelumpemberian tindakan dengan setelah pemberian tindakan pada siklus I dan siklus II. Peningkatan yang baik dicapai setelah diberikannya tindakan dengan 
penerapanmetode problem posing dari siklus I ke siklus II sebesar 11,76\%. Dimana dari hasil tesyang diberikan persentase ketuntasan siswa mencapai $94,11 \%$ dengan rata-ratanilai 73,23 . Secara klasikal siklus II dinyatakan telah memenuhi kriteria penilaian.

Siswa dapat memahami konsep-konsep materi pembelajaran dengan baik karena siswa terlibat aktif pada saat proses kegiatan belajar. Siswa mencari tahu hal-hal penting mengenai materi melalui berpikir, bertukar pikiran dengan teman pasangannya serta mempresentasikan hasil diskusinya. Hasil belajar siswa ini digunakan untuk mengetahui sejauh mana pemahaman siswa terhadap materi pembelajaran yang telah disampaikan.

Melihat hasil tersebut Maka penelitian sepakat untuk tidak meneruskan ke siklus selanjutnya karena indikator keberhasilan dalam penelitian ini sudah tercapai. Oleh karena itu, penelitian dihentikan hanya sampai siklus kedua.

Melihat kenyataan diatas, maka penerapan metode problem posing dalam pembelajaran Bahasa Indonesia. Walaupun masih ada anak yang mengalami berbagai kesalahan, namun secara keseluruhan dapat dikatakan mengalami peningkatan secara bertahap. Selain itu, melalui pendekatan problem posing siswa bisa menemukan lebih dari satu alternatif jawaban. Hal tersebut sesuai dengan literature Yaya S. Kusumah (2004) yang menyatakan bahwa
Pendekatan ini lebih ditekankan pada kegiatan membentuk soal yang dilakukan oleh siswa sendiri. Hal ini memberi kesempatan yang luas kepada siswa untuk mengkonstruk pengetahuan sesuai dengan perkembangan pengetahuan berfikirnya.

Problem posing merupakan pendekatan pembelajaran yang mengarah kepada kemampuan siswa, yaitu berpikir kritis, logis, cermat, sistematis, kreatif dan inovatif yang dapat ditumbuhkembangkan. Disamping itu beberapa sikap positif yang sangat berguna dalam pemecahan masalah, seperti percaya diri, pantang menyerah, ulet dan disiplin dapat muncul terbina melalui problem posing.

Guru berperan untuk menciptakan kondisi yang kondusif dan mendukung bagi terciptanya pembelajaran yang bermakna. Siswa (peserta didik) harus mengalami dan berinteraksi langsung dengan obyek yang nyata. Jadi belajar harus dialihkan yang semula berpusat pada guru menjadi pembelajaran yang berpusat pada siswa.

Dari hasil tes ini dapat dilihat bahwa hasil belajar dengan menggunakan metode pembelajaran problem posing telah mampu meningkatkan hasil belajar siswa mengenai materi pelajaran bahasa Indonesia sesuai dengan indikator yang telah ditentukan sehingga tidak 
perlu lagi dilanjutkan pada siklus berikutnya dan dikatakan berhasil.

Berdasarkan hasil yang didapat dari setiap siklus proses pembelajaran yang optimal, hal ini ditunjukkan dengan meningkatnya penguasaan materi dan hasil belajar siswa. Oleh karena itu dapat disimpulkan bahwa proses pembelajaran dengan penerapan inkuiris angat sesuai dengan mata pelajaran Bahasa Indonesia. maka Penelitian Tindakan Kelas (PTK) ini bisa dikatakan berhasil karena hasil peningkatan proses pembelajarannya optimal.

Gambaran peningkatan ketuntasan belajar yang diperoleh setelah melakukan penelitian dengan menggunakan metode problem posing terlihat pada diagram berikut:

\section{Grafik 1. Peningkatan Ketuntasan} Belajar

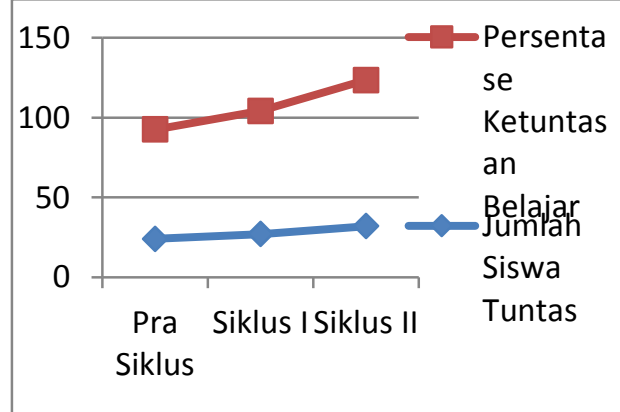

\section{SIMPULAN}

Dari hasil temuan penelitian tentang hasil belajar siswa dengan metode problem posing di kelas IV SD Negeri 163099 Tebing Tinggi tahun pelajaran 2016/2017 berdampak positif dalam meningkatkan hasil belajar siswa. Hal tersebut dapat dilihat dari peningkatan persentase ketuntasan belajar siswa pada pra siklus $(73,52 \%)$, siklus I $82,35 \%)$, siklus II $(94,11 \%)$.

Atas dasar simpulan dan implikasi hasil penelitian tindakan kelas di atas, penulis memberikan saran-saran sebagai berikut :

\section{Bagi Sekolah}

Sekolah perlu memberikan dukungan kepada guru dalam menambah wawasan dan meningkatkan keterampilan dalam mengajar agar keberhasilan dalam proses pembelajaran di kelas tercapai. Dengan demikian guru akan mengetahui keberhasilan dan kekurangan pembelajaran yang telah dilakukannya.

\section{Bagi Guru}

Guru perlu lebih kreatif dalam merancang pembelajaran yang memberikan kesempatan kepada siswa untuk menemukan kembali pengetahuan. Hal ini dapat dilakukan dengan menggunakan model-model pembelajaran inovative sehingga siswa dapat menyelesaikan permasalahan dalam kelompok dan siswa lebih aktif dalam proses pembelajaran.

\section{Bagi Siswa}

Siswa diharapkan dapat meningkatkan aktivitas dan hasil belajar bahasa Indonesia sehingga siswa dapat memahami lebih cepat 
konsep-konsep di dalam pembelajaran.

DAFTAR RUJUKAN

Anni, Catharina Tri, dkk. 2007. Psikologi Belajar. Cetakan keempat. Semarang: UPT UNNES Press.

Cankoy, O \& Darbaz, S. (2010). Effect Problem Possing Based on Problem Solving Instruction on Understanding Problem. Journal of Education 38, 11-24. Diperoleh 17 April 2012, dari http: //efdergi. Hacettepe .edu.

tr/english/OSMAN\%20CAN KOY.pdf

Syarifulfahmi. (2009). LangkahLangkah Pelaksanaan Problem Posing. Diperoleh dari http://syarifulfahmi.blogspot. com/2009/09/pendekatanpembelajaran-problemposing.html.\%20\%2821 tanggal 30 Maret 2013.

Sanjaya, Wina. 2010. Penelitian Tindakan Kelas. Jakarta: Kencana Prenada Media Group.

Yaya S. Kusumah. (2004). Modelmodel Pembelajaran Matematika untuk Meningkatkan Kemampuan Kognitif dan Afektif Siswa Sekolah Menengah. Disampaikan dalam Seminar Nasional Matematika yang Diselenggarakan Jurusan
Pendidikan Matematika FMIPA Universitas Negeri Yogyakarta (UNY). Bandung: Jurusan Matematika FMIPA Universitas Pendidikan Indonesia.

Yusi Rosdiana, dkk. 2007. Bahasa dan Sastra Indonesia SD. Jakarta: Universitas Terbuka. 